\title{
Electrochemical impedance study on the corrosion of Al-Pure in hydrochloric acid solution using Schiff bases
}

\author{
A S PATEL, V A PANCHAL and N K SHAH* \\ Department of Chemistry, School of Sciences, Gujarat University, Ahmedabad 380 009, India
}

MS received 12 November 2010; revised 25 January 2011

\begin{abstract}
The inhibition effect of newly synthesized Schiff bases $N$-benzylidene benzylamine (A) and benzenemethanamine- $\alpha$-methyl- $N$-(phenylmethylene) (B) on the corrosion behaviour of Al-Pure in 1.0 M HCl was studied using galvanostatic polarization and electrochemical impedance spectroscopy (EIS) and adsorption studies. The effects of inhibitor concentration, temperature and surface coverage are investigated. The effect of inhibitor concentration and other parameters are evaluated for different inhibitor concentrations and the probable mechanism was also proposed. The results show that (A) and (B) possess excellent inhibiting effect for the corrosion of Al-Pure and the inhibitors act as mixed type inhibitors. The inhibitors do not affect the mechanism of the electrode processes and inhibit corrosion by blocking the reaction sites. The high inhibition efficiency of (A) and (B) were due to the adsorption of inhibitor molecules on the metal surface. The decrease of surface area available for electrode reactions to take place is due to the formation of a protective film. Activation energy and free energy of adsorption have been calculated.
\end{abstract}

Keywords. Al-Pure; electrochemical impedance spectroscopy (EIS); corrosion; adsorption; inhibitor.

\section{Introduction}

Corrosion is defined as the deterioration of the material, usually a metal, because of reaction with its environment and which requires the presence of an anode, a cathode, an electrolyte and an electrical circuit (Rosliza et al 2010).

Aluminium and its alloys have a low density, an attractive appearance, relatively good corrosion resistance and excellent thermal and electrical conductivities. The combination of these properties makes it a preferred choice for many industrial applications such as automobiles, food-handling containers, electronic devices, building, aviation, etc. (Talbot and Talbot 1998; Li et al 2005; Sherif and Park 2006). Various attempts (Stevanovic et al 1988; Tomcsanyi et al 1989; Ovari et al 1998; Ashassi-Sorkhabi et al 2006; Khaled and Qahtani 2009) have been made to study the corrosion of aluminium and its alloys, and their inhibition by organic inhibitors in acid solutions.

Hydrochloric acid solutions are used for pickling of aluminium and for its chemical or electrochemical etching. It can be important to add a corrosion inhibitor to decrease the rate of aluminium dissolution in such solutions. Thus, numerous studies concerning the inhibition of aluminium corrosion using organic substances have been conducted in acidic and basic solutions (Abdel Kader and El Din Shams 1970; Sampat and Vora 1974; Shalaby et al 1976; El Mahdy and Mahmoud 1995). Organic compounds have been accepted as effective inhibitors for metal corrosion in various solutions (Ashassi-Sorkhabi et al 2009). These compounds,

\footnotetext{
*Author for correspondence (nishchem2004@yahoo.co.in)
}

which are usually organic substances containing nitrogen, sulfur, and/or oxygen in the conjugated system, are reported as efficient corrosion inhibitors, which act through adsorption on the metal surface, forming a complex with metal ions and thereby retarding metal dissolution; polar groups act as the reaction centre for the adsorption process. Despite the large number of organic compounds, there is always a need for developing new organic corrosion inhibitors (Desai et al 1986; Ajmal et al 1994; Abd and El-Maksoud 2002).

Some Schiff bases have recently reported as effective corrosion inhibitors for steel (Bain et al 1989; Emregul et al 2003), aluminium (Gomma and Wahdan 1995), aluminium alloys (Hahner et al 1993; Aytac et al 2005) and copper (Li et al 1999) in acidic media. Due to the presence of the $-\mathrm{C}=\mathrm{N}-$ group, electronegative nitrogen, sulphur and/or oxygen atoms in the molecule, Schiff bases should be good corrosion inhibitors. The action of such inhibitors depends on the specific interaction between the functional groups and the metal surface. So it is very important to clarify the interactions between the inhibitor molecules and metal surfaces in order to search new and efficient corrosion inhibitors (Yurt et al 2006).

In earlier work the inhibition of corrosion of zinc in sulphuric acid by Schiff bases of ethylenediamine (Shah et al 2004), ortho-substituted aniline- $N$-salicylidenes (Desai et al 2003), ortho-, meta-, and para-aminophenol$N$-salicylidenes (Talati et al 2005b), and meta-substituted aniline- $N$-salicylidenes (Talati et al 2005a) is reported.

In the present work, the inhibitive effectiveness of (A) and (B) Schiff bases is studied in retarding corrosion of Al-Pure in $1.0 \mathrm{M} \mathrm{HCl}$. Weight loss method, galvanostatic 
polarization and electrochemical impedance spectroscopy (EIS) techniques were used to investigate the inhibiting influence of (A) and (B) organic Schiff base compounds.

\section{Experimental}

The used Schiff base compounds were synthesized from equimolar amounts of benzaldehyde and corresponding amines (benzylamine and $D(+) \alpha$-phenylethylamine) through a condensation reaction in ethanol media. The chemical structures of used Schiff bases are characterized by IR (figure 1), which are given below:<smiles>C(=N/Cc1ccccc1)\c1ccccc1</smiles>

(A)<smiles>CC(/N=C/c1ccccc1)c1ccccc1</smiles>

(B)
Rectangular specimens of Al-Pure, of size $6.0 \mathrm{~cm} \times$ $3.0 \mathrm{~cm}$ (thickness $=0.050 \mathrm{~cm}$ ), were polished to mirror

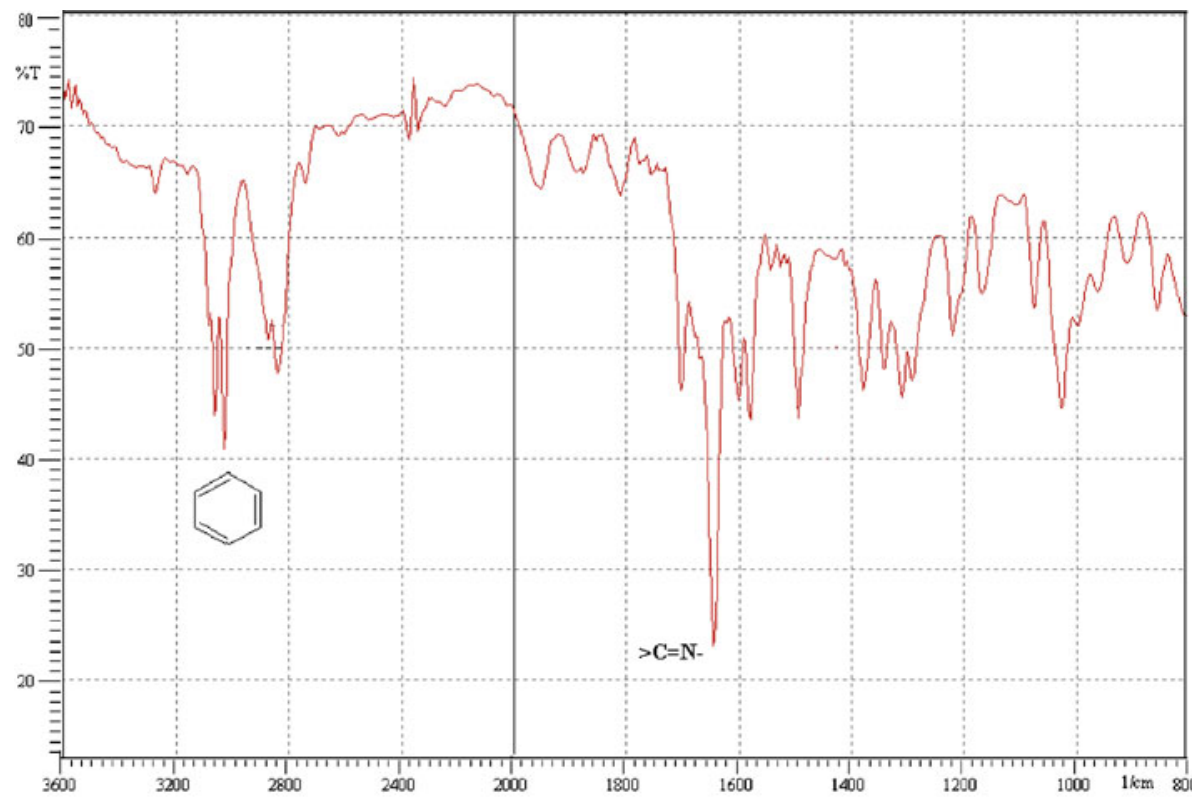

(I) $N$-benzylidene benzylamine (A)

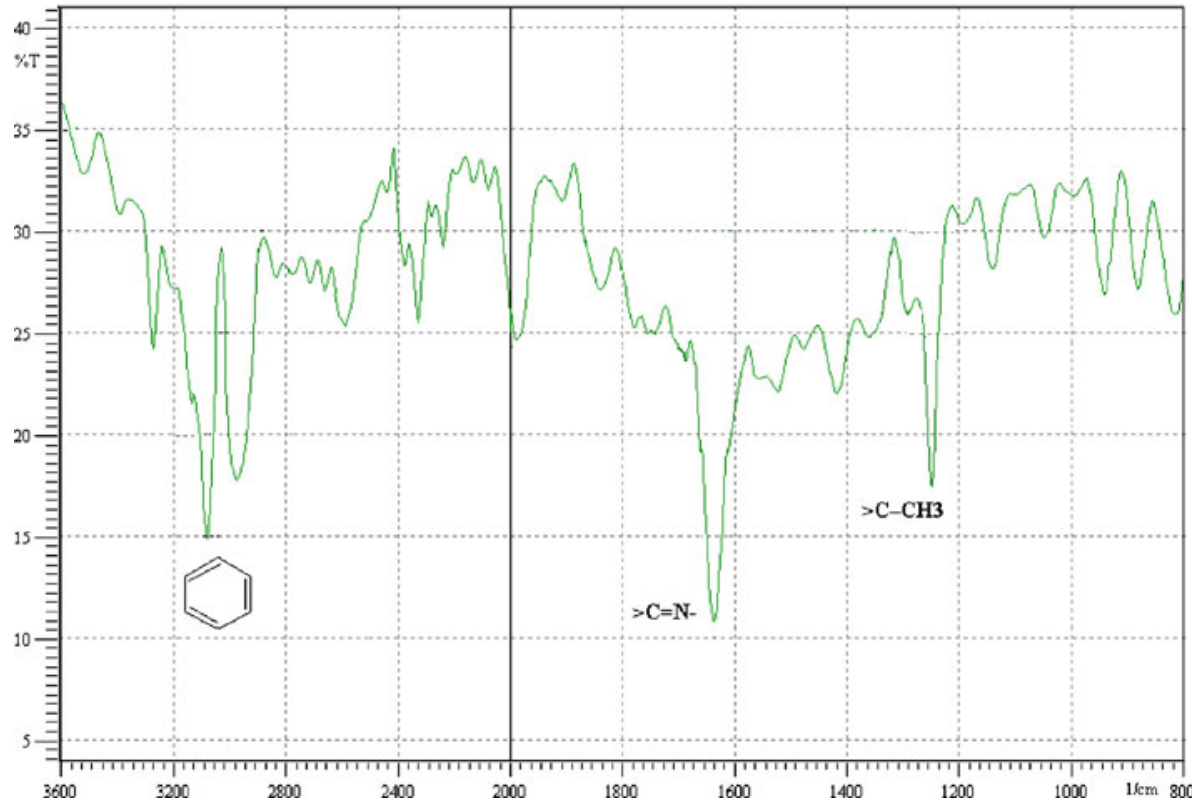

(II) Benzenemethanamine- $\alpha$-methyl- $N$-(phenylmethylene) (B)

Figure 1. IR spectra of (I) $N$-benzylidene benzylamine (A) and (II) benzenemethanamine- $\alpha$ methyl- $N$-(phenylmethylene) (B). 
finish, degreased with AR carbon tetrachloride (sulphur free) and used for the weight loss method. The specimens were immersed in $230 \mathrm{ml}$ of the solution containing various concentrations of the inhibitors in the absence and presence of (A) and (B) inhibitors, at $35^{\circ} \mathrm{C} \pm 0.5^{\circ} \mathrm{C}$ for an exposure period of $60 \mathrm{~min}$. The weight of the specimen before and after immersion was determined using mettler balanceM5 type. Triplicate experiments were performed. Experiments (the loss in weight of specimen) were carried out in $0.5 \%$ concentration of inhibitors at temperature ranging from $35^{\circ} \mathrm{C} \pm 0.5^{\circ} \mathrm{C}$ to $65^{\circ} \mathrm{C} \pm 0.5^{\circ} \mathrm{C}$.

Polarization and EIS studies were carried out using a three electrode cell assembly; Al-Pure was used as working electrode, platinum as counter electrode and saturated calomel electrode (SCE) as reference electrode. The corrosion parameters such as corrosion potential $\left(E_{\text {corr }}\right)$, corrosion current density $\left(I_{\text {corr }}\right)$ and Tafel plots were measured in polarization method. In this study, the current density was varied in the range of $2 \times 10^{-4}-3.25 \times 10^{-2} \mathrm{~A} \mathrm{~cm}^{-2}$. Electrochemical impedance measurements were carried out in the frequency range of $20 \mathrm{kHz}-0 \cdot 1 \mathrm{~Hz}$ at the open circuit potential (for EIS limitation of current supply is in between $10 \mathrm{nA}$ and $10 \mathrm{~mA}$ ), after $1 \mathrm{hr}(60 \mathrm{~min})$ of immersion, by applying amplitude of $0.5 \mathrm{mV}$ sine wave ac signal. Double layer capacitance $\left(C_{\mathrm{dl}}\right)$ and charge transfer resistance $\left(R_{\mathrm{ct}}\right)$ values were calculated from Nyquist plots as described by Hosseini et al (2003). EIS data was analyzed using frequency response analyzer (FRA) electrochemical setup.

\section{Results and discussion}

\subsection{Weight loss measurements}

3.1a Effect of inhibitor concentration: When Al-Pure was immersed in $1.0 \mathrm{M}$ hydrochloric acid at $35^{\circ} \mathrm{C} \pm 0.5^{\circ} \mathrm{C}$ for exposure period of $60 \mathrm{~min}$, it suffered a weight loss of

Table 1. Corrosion parameters for Al-pure in presence and absence of different concentrations of Schiff bases obtained from weight loss measurements at $35^{\circ} \mathrm{C} \pm 0.5^{\circ} \mathrm{C}$ for exposure period of $60 \mathrm{~min}$.

\begin{tabular}{|c|c|c|c|c|}
\hline Inhibitor & $\begin{array}{l}\text { Concentration } \\
(\% \mathrm{v} / \mathrm{v})\end{array}$ & $\begin{array}{l}\text { Weight loss } \\
\left(\mathrm{mg} \mathrm{dm}^{-2}\right)\end{array}$ & $\begin{array}{c}\text { Surface coverage } \\
\qquad(\theta)\end{array}$ & $(\% \mathrm{P})$ \\
\hline Blank & - & 2300 & - & - \\
\hline \multirow[t]{5}{*}{ (A) } & $0 \cdot 001$ & 911 & 0.604 & $60 \cdot 4$ \\
\hline & $0 \cdot 01$ & 650 & 0.717 & $71 \cdot 7$ \\
\hline & 0.05 & 325 & 0.859 & $85 \cdot 9$ \\
\hline & $0 \cdot 10$ & 190 & $0 \cdot 917$ & 91.7 \\
\hline & 0.50 & 16 & 0.993 & $99 \cdot 3$ \\
\hline \multirow[t]{5}{*}{ (B) } & $0 \cdot 001$ & 827 & 0.640 & $64 \cdot 0$ \\
\hline & $0 \cdot 01$ & 569 & 0.753 & $75 \cdot 3$ \\
\hline & 0.05 & 276 & $0 \cdot 880$ & $88 \cdot 0$ \\
\hline & $0 \cdot 10$ & 154 & 0.933 & $93 \cdot 3$ \\
\hline & 0.50 & 11 & 0.995 & 99.5 \\
\hline
\end{tabular}

$2300 \mathrm{mg} \mathrm{dm}^{-2}$. Table 1 shows that the inhibition efficiency of Al-pure in $1.0 \mathrm{M} \mathrm{HCl}$ in presence of different concentrations of inhibitors (A) and (B) at $35^{\circ} \mathrm{C} \pm 0 \cdot 5^{\circ} \mathrm{C}$.

The percentage inhibition efficiency $(\% \mathrm{P})$ was calculated using the following equation:

$$
\text { Inhibitor efficiency }(\% \mathrm{P})=\frac{W_{\mathrm{u}}-W_{\mathrm{i}}}{W_{\mathrm{u}}} \times 100 \text {, }
$$

where $W_{\mathrm{u}}$ is the weight loss of Al-Pure in uninhibited acid and $W_{\mathrm{i}}$ the weight loss of Al-Pure in inhibited acid, respectively.

It is observed from table 1 , that the weight loss decreased and therefore the corrosion inhibition strengthened, with increase in inhibitor concentration. This trend may result from the fact that adsorption and surface coverage increases with the increase in concentration. Thus the surface is efficiently separated from the medium (Al-Andis et al 1995).

3.1b Adsorption isotherm: The inhibitor efficiency depends on the type and number of active sites at the metal surface, the charge density, the molecular size of the inhibitor, the metal-inhibitor interaction and the metallic complex formation (Avc 2008). The adsorption isotherm can give information on the metal-inhibitor interaction. The type of adsorption of (A) and (B) Schiff bases was elucidated from the degree of surface coverage value $(\theta)$ which is calculated from the following equation and the values are mentioned in table 1 .

$$
\theta=\frac{W_{\mathrm{u}}-W_{\mathrm{i}}}{W_{\mathrm{u}}},
$$

where $W_{\mathrm{u}}$ is the weight loss of Al-Pure in uninhibited acid and $W_{\mathrm{i}}$ the weight loss of Al-Pure in inhibited acid, respectively.

The values of surface coverage, $\theta$ for the inhibitors were used to explain the best isotherm to determine the adsorption process. Attempts were made to fit $\theta$ values to various adsorption isotherms namely Langmuir, Freundlich and Temkin. By far the best fits were obtained with Langmuir adsorption isotherm.

When plots of $\log (\theta / 1-\theta)$ vs $\log C_{\text {inh }}$ (inhibitor concentration) were drawn (figure 2), straight lines were obtained (up to a certain concentration), indicating that the adsorption of the inhibitors (A) and (B) takes place following Langmuir adsorption isotherm (Desai et al 2008), which shows that the formed film is monolayer type.

$$
C_{\text {inh }}=\frac{\theta}{K(1-\theta)} .
$$

When the inhibitor efficiency (i.e. $\theta$ ) is quite high and becomes almost constant, the plot deviates and runs somewhat parallel to the abscissa.

3.1c Effect of temperature: Temperature has a great effect on the corrosion phenomenon. Generally the corrosion rate increases with the rise in temperature. For this purpose, 


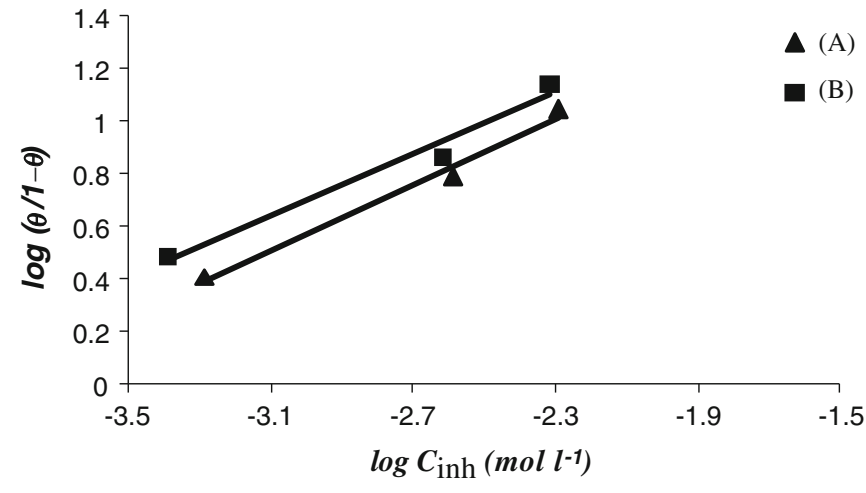

Figure 2. Langmuir isotherm for adsorption of Schiff bases on the Al-Pure metal surface.

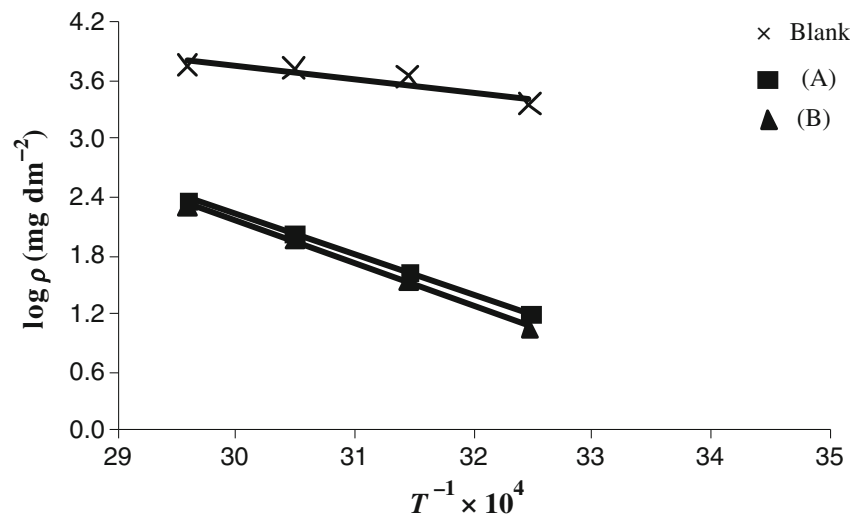

Figure 3. Plotting $\log \rho$ vs. $T^{-1} \times 10^{4}$ to calculate the activation energy of corrosion process in the presence and absence of inhibitors.

Table 2. Effect of temperature on weight loss and inhibition efficiency for Al-Pure in $1.0 \mathrm{M} \mathrm{HCl}$.

\begin{tabular}{lccccc}
\hline & \multirow{2}{*}{$\begin{array}{c}\text { Concentration } \\
\text { Inhibitor }\end{array}$} & \multicolumn{4}{c}{ Weight loss $\left(\mathrm{mg} \mathrm{dm}^{-2}\right)$ at temperature } \\
\cline { 3 - 6 } & $(\% \mathrm{v} / \mathrm{v})$ & $35^{\circ} \mathrm{C}$ & $45^{\circ} \mathrm{C}$ & $55^{\circ} \mathrm{C}$ & $65^{\circ} \mathrm{C}$ \\
\hline Blank & - & 2300 & 4436 & 5303 & 5808 \\
(A) & 0.5 & $16(99.3 \%)$ & $43(99.0 \%)$ & $108(98.0 \%)$ & $238(95.5 \%)$ \\
(B) & 0.5 & $11(99.5 \%)$ & $35(99.2 \%)$ & $89(98.3 \%)$ & $203(96.5 \%)$ \\
\hline
\end{tabular}

we made weight loss measurements in the temperature range of $35^{\circ} \mathrm{C} \pm 0.5^{\circ} \mathrm{C}$ to $65^{\circ} \mathrm{C} \pm 0.5^{\circ} \mathrm{C}$, in the absence and presence of $0.5 \%$ concentration of (A) and (B) inhibitors after 60 min of immersion. The corresponding data are shown in table 2.

From the table 2, it is clear that the inhibition efficiencies are found to decrease with increasing the solution temperature from $35^{\circ} \mathrm{C} \pm 0.5^{\circ} \mathrm{C}$ to $65^{\circ} \mathrm{C} \pm 0.5^{\circ} \mathrm{C}$. This behaviour can be interpreted on the basis that the increases in temperature results in desorption of the inhibitors from the surface of Al-Pure.

3.1d Thermodynamic parameters: Plotting $\log \rho$ (corrosion rate, $\mathrm{mg} \mathrm{dm}^{-2}$ ) vs $T^{-1} \times 10^{4}$ gave straight lines with slope of $-E_{\mathrm{a}} / R$ (figure 3 ). The apparent activation energy $\left(E_{\mathrm{a}}\right)$ for the Al-Pure dissolution process can be evaluated from the following relationship (Eyring and Eyring 1967):

$$
\rho=k \exp \left(-E_{\mathrm{a}} / R T\right),
$$

where $\rho$ is the corrosion rate, $E_{\mathrm{a}}$ the activation energy, $T$ the temperature and $k$ is the constant. Calculated activation energies are given in table 3 . As we see from these data, activation energies strongly increase in the presence of inhibitors. This fact indicates that the adsorption of these inhibitors occurs through physical adsorption (Ashassi-Sorkhabi et al 2005).

If it is assumed that the inhibitor is adsorbed on the metal surface in the form of a monolayer film, covering at any instant a fraction, $\theta$, of the metal surface in a uniform random manner, then the heat of adsorption, $\left(Q_{\mathrm{ads}}\right)$, of the inhibitors can be calculated from the equation:

$$
Q_{\mathrm{ads}}=2.303 R\left\{\log \frac{\theta_{2}}{1-\theta_{2}}-\log \frac{\theta_{1}}{1-\theta_{1}}\right\}\left(\frac{T_{1} T_{2}}{T_{2}-T_{1}}\right) .
$$

The values of the free energy of adsorption $\left(\Delta G_{\mathrm{ads}}\right)$ were calculated from the following equation (Desai et al 2008):

$$
\log C_{\mathrm{inh}}=\log \frac{\theta}{1-\theta}-\log B,
$$

where

$$
\log \mathrm{B}=-1.74-\left(\Delta G_{\mathrm{ads}} / 2.303 R T\right) .
$$

The values of $\left(\Delta G_{\text {ads }}\right)$ and $\left(Q_{\text {ads }}\right)$ are shown in table 3 . The negative value of $\left(\Delta G_{\mathrm{ads}}\right)$ suggests that the inhibitor molecules are strongly adsorbed on the metal surface, the values also indicate a spontaneous adsorption of the inhibitor molecules usually characterized by the strong interactions with the metal surface. It is found that the $\left(\Delta G_{\text {ads }}\right)$ values are positive than $-40 \mathrm{~kJ} \mathrm{~mol}^{-1}$ indicating that inhibitor molecules are physically adsorbed on the metal surface (Desai and Vashi 2010). The negative values of $\left(Q_{\text {ads }}\right)$ indicated that the adsorption of used inhibitors on the Al-Pure surface is exothermic. 
Table 3. Thermodynamic parameters and activation energy for inhibitor adsorption for corrosion of Al-Pure in $1.0 \mathrm{M} \mathrm{HCl}$ (inhibitor concentration $0 \cdot 5 \%$ ).

\begin{tabular}{lccc}
\hline Inhibitor & $\begin{array}{c}E_{\mathrm{a}} \\
\left(\mathrm{kJ} \mathrm{mole}^{-1}\right)\end{array}$ & $\begin{array}{c}Q_{\mathrm{ads}} \\
\left(\mathrm{kJ} \mathrm{mole}^{-1}\right)\end{array}$ & $\begin{array}{c}\Delta G_{\mathrm{ads}} \\
\left(\mathrm{kJ} \mathrm{mole}^{-1}\right)\end{array}$ \\
\hline Blank & 25.9 & - & - \\
(A) & 79.5 & -54.0 & -31.8 \\
(B) & 85.8 & -59.4 & -32.6 \\
\hline
\end{tabular}

\subsection{Galvanostatic polarization study}

The galvanostatic polarization curves for Al-Pure in $1.0 \mathrm{M}$ $\mathrm{HCl}$ solution with two concentrations of inhibitors (A) and (B) at $35^{\circ} \mathrm{C} \pm 0.5^{\circ} \mathrm{C}$ are shown in figure 4 . It could be observed that addition of the inhibitors causes more negative shift in corrosion potential $\left(E_{\text {corr }}\right)$ especially in high concentrations, which means that the inhibitors affect cathodic reaction more than anodic reaction.

From the figure 4, it was observed that in the presence of (A) and (B) inhibitors, both of the cathodic and anodic curves show lower current density than those observed in the uninhibited solution (without the inhibitors). These show that the inhibitors are adsorbed on the metal surface and covers both, the anodic as well as the cathodic regions. It is also observed that with lower inhibitor concentration the potentials are less negative but as the inhibitor concentration is increased the potentials become more negative. This suggests that first the inhibitor is adsorbed on the anodic sites as well as cathodic sites but as its concentration increases the cathodic sites are more covered than anodic sites. Galvanostatic polarization curves show negligible anodic but significant cathodic polarization in inhibited acid. Therefore, these compounds could be classified as mixed type inhibitors with a predominantly cathodic action.

The values of cathodic Tafel slope $\left(b_{\mathrm{c}}\right)$ and anodic Tafel slope $\left(b_{a}\right)$ were calculated from the linear region of the polarization curves are given table 4 . The corrosion current density $\left(I_{\text {corr }}\right)$ was determined from the intersection of the linear parts of the cathodic curves with stationary corrosion potential $\left(E_{\text {corr }}\right)$.

The percentage inhibition efficiency $(\% \mathrm{P})$ was calculated using the following equation:

$$
(\% \mathrm{P})=\frac{I_{\text {corr }}^{0}-I_{\text {corr }}}{I_{\text {corr }}^{0}} \times 100,
$$

where $I_{\text {corr }}^{0}$ and $I_{\text {corr }}$ are the corrosion current densities in the absence and presence of the inhibitor, respectively.

\subsection{Electrochemical impedance spectroscopy (EIS)}

The corrosion behaviour of $\mathrm{Al}-\mathrm{Pure}$ in $1.0 \mathrm{M} \mathrm{HCl}$ solution in the absence and presence of $(\mathrm{A})$ and $(\mathrm{B})$ inhibitors were also
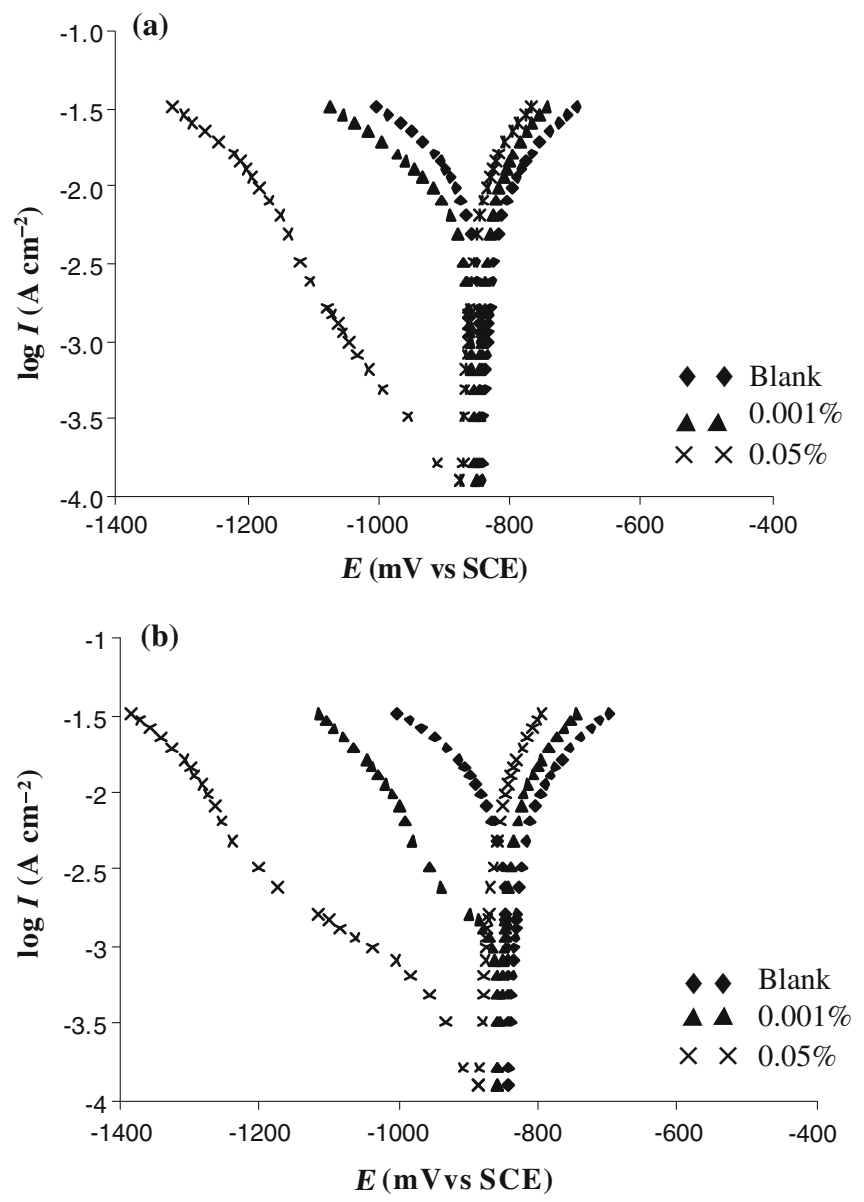

Figure 4. Anodic and cathodic polarization curves obtained for Al-Pure metal at $35^{\circ} \mathrm{C} \pm 0.5^{\circ} \mathrm{C}$ in $1.0 \mathrm{M} \mathrm{HCl}$ in various concentration of studied Schiff bases: (a) compound A and (b) compound B.

investigated using electrochemical impedance spectroscopy (EIS). Nyquist plots of Al-Pure in uninhibited and inhibited acid solutions containing various concentrations of inhibitor are given in figure 5 . As can be seen, the impedance response of Al-Pure in uninhibited $1.0 \mathrm{M} \mathrm{HCl}$ solution significantly changed after addition of inhibitors. The equivalent circuit model used to fit the experimental results is shown in figure 6.

The FRA (frequency response analyzer) is used for impedance data analysis and the fit parameters are listed in table 5 . Where $R_{\mathrm{ct}}, R_{\mathrm{s}}$ and $C_{\mathrm{dl}}$ are the charge transfer resistance, solution resistance and double layer capacitance, respectively. From the impedance measurements, inhibition efficiencies were calculated using the following expression:

$$
(\% \mathrm{P})=\frac{R_{\mathrm{ct}}-R_{\mathrm{ct}}^{0}}{R_{\mathrm{ct}}} \times 100,
$$

where $R_{\mathrm{ct}}$ and $R_{\mathrm{ct}}^{0}$ are the charge transfer resistance of the electrode with and without the inhibitors, respectively. The results show that there is an increase in $R_{\mathrm{ct}}$ values with the addition of the inhibitors when compared with those without 
Table 4. Electrochemical parameters of corrosion of Al-Pure in the presence of different concentration of inhibitors at $35^{\circ} \mathrm{C} \pm 0 \cdot 5^{\circ} \mathrm{C}$ and corresponding inhibition efficiencies obtained from polarization method.

\begin{tabular}{lcccccc}
\hline Inhibitor & $\begin{array}{c}\text { Concentration } \\
(\% \mathrm{v} / \mathrm{v})\end{array}$ & $\begin{array}{c}E_{\text {corr }} \\
(\mathrm{mV})\end{array}$ & $\begin{array}{c}b_{\mathrm{a}} \\
(\mathrm{mV} / \mathrm{dec})\end{array}$ & $\begin{array}{c}b_{\mathrm{c}} \\
(\mathrm{mV} / \mathrm{dec})\end{array}$ & $\begin{array}{c}I_{\text {corr }} \\
\text { for cathodic }\left(\mathrm{A} \mathrm{cm}^{-2}\right)\end{array}$ & $(\% \mathrm{P})$ \\
\hline Blank & - & -843 & 113 & 120 & $4.467 \times 10^{-3}$ & - \\
(A) & 0.001 & -852 & 64 & 100 & $1.949 \times 10^{-3}$ & $56 \cdot 4$ \\
& $0 \cdot 05$ & -876 & 77 & 170 & $1.862 \times 10^{-4}$ & $95 \cdot 8$ \\
(B) & 0.001 & -858 & 62 & 145 & $8.912 \times 10^{-4}$ & $80 \cdot 1$ \\
& $0 \cdot 05$ & -887 & 75 & 196 & $1.174 \times 10^{-4}$ & $97 \cdot 4$ \\
\hline
\end{tabular}

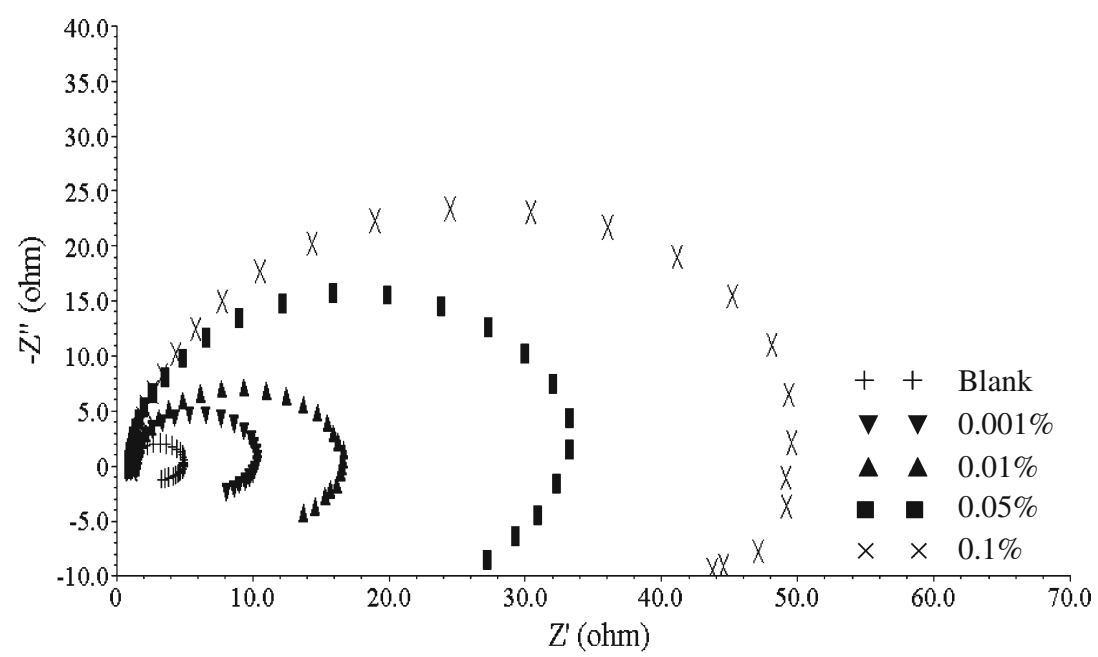

(a)

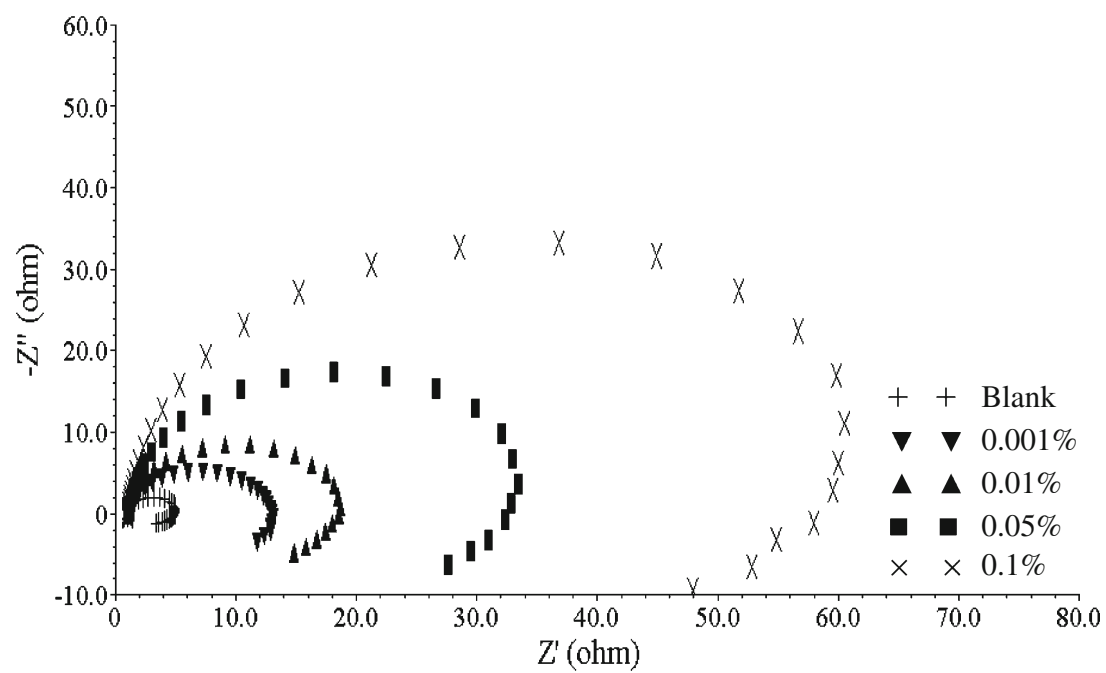

(b)

Figure 5. Impedance plot obtained at $35^{\circ} \mathrm{C}$ in $1.0 \mathrm{M} \mathrm{HCl}$ in various concentrations of Schiff bases: (a) compound A and (b) compound B.

the inhibitors. Furthermore, the values of $R_{\mathrm{ct}}$ are increasing with increase in inhibitor's concentration. It should be noted that while $R_{\mathrm{ct}}$ values increase with the addition of inhibitors, the $C_{\mathrm{dl}}$ values decrease indicating the formation of a surface film. Thus, increase in $R_{\mathrm{ct}}$ values and decrease in $C_{\mathrm{dl}}$ values by the inhibitors are related to the increased degree of protection of Al-Pure in $1.0 \mathrm{M} \mathrm{HCl}$. The electrochemical theory shows that $C_{\mathrm{dl}}$ is proportional to the corrosion rate. 


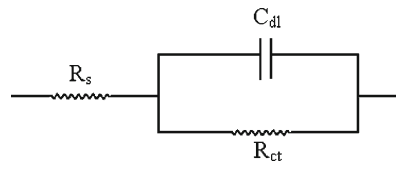

Figure 6. The equivalent circuit model used to fit the experimental results.

Table 5. Impedance parameters and corresponding inhibition efficiency for the corrosion of Al-Pure in the $1.0 \mathrm{M} \mathrm{HCl}$.

\begin{tabular}{lccccc}
\hline Inhibitor & $\begin{array}{c}\text { Concentration } \\
(\% \mathrm{v} / \mathrm{v})\end{array}$ & $\begin{array}{c}R_{\mathrm{S}} \\
(\mathrm{Ohm})\end{array}$ & $\begin{array}{c}R_{\mathrm{ct}} \\
(\mathrm{Ohm})\end{array}$ & $\begin{array}{c}C_{\mathrm{dl}} \\
(\mu \mathrm{F})\end{array}$ & $\begin{array}{c}P \\
(\%)\end{array}$ \\
\hline Blank & - & 1.079 & 3.99 & 85.73 & - \\
$(\mathrm{A})$ & 0.001 & 1.057 & 9.77 & 83.10 & 59.2 \\
& 0.01 & 1.408 & 14.51 & 80.87 & 72.5 \\
& 0.05 & 0.942 & 32.71 & 75.89 & 87.8 \\
& 0.10 & 1.156 & 49.50 & 70.85 & 91.9 \\
& 0.001 & 1.018 & 11.22 & 83.14 & 64.4 \\
& 0.01 & 1.029 & 17.41 & 78.30 & 77.1 \\
& 0.05 & 1.158 & 36.40 & 73.09 & 89.0 \\
& 0.10 & 1.035 & 67.11 & 68.26 & 94.1 \\
\hline
\end{tabular}

\subsection{Mechanism of the inhibition}

Most organic corrosion inhibitors are compounds with at least one polar unit containing atoms of nitrogen, sulphur, oxygen and in some cases selenium and phosphorous. The polar unit is regarded as the reaction centre for the establishment of the adsorption process and the adsorption bond strength is determined by the electron density of the atom acting as the reaction centre and by the polarisability of the fundamental unit. According to Hackermann (1954), aminetype inhibitors have electron-donating ability and their action is attributed to the adsorption of the molecule on the metal surface through an unshared pair of electrons belonging to the nitrogen atom. The inhibitor molecules are adsorbed chemically on the surface of the bulk metal, $M$, forming a charge transfer complex between the polar atom/atoms and the metal,

$$
M+\mathrm{RnX} \leftrightarrow M: \mathrm{XRn} .
$$

Further, these inhibitors, which are in a distinct ionic form, also may get attached to the metal surface of opposite polarity through electrostatic attraction. The adsorbed layer then will block the dissolution of the metal. The size, orientation and shape of the molecule, and the electronic charge on it, will determine the degree of adsorption and hence the effectiveness of the inhibitor.

Both (A) and (B) inhibitors are characterized by IR (figure 1), two main peaks are observed, first at $\sim 3100 \mathrm{~cm}^{-1}$ for aromatic ring and second at $\sim 1620 \mathrm{~cm}^{-1}$ for iminic group. The adsorption takes place due to the iminic group, therefore the inhibitive efficiency of the both (A) and (B) should be almost the same.
It is also possible that the compounds may form onium ions in acidic medium and move to the cathodic regions and then the adsorption will take place through the iminic nitrogen and also through the delocalized $\pi$-electrons of the benzene moiety. Then molecule will lie flat on the metal surface and further cover the adjoining positions of the surface.

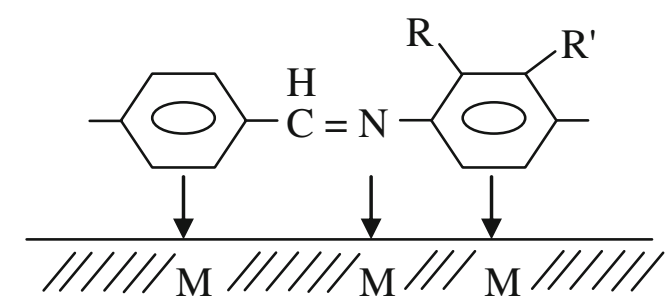

\section{Conclusions}

(I) The effect of two inhibitors (A) and (B) are studied on Al-Pure by using weight loss, galvanostatic polarization and EIS methods. Results showed that efficiency of inhibitors increase with increase in the inhibitor concentration but decrease with increase in temperature and inhibitors follow the Langmuir adsorption isotherm.

(II) The values of $\left(\Delta G_{\mathrm{ads}}\right)$ and $\left(Q_{\mathrm{ads}}\right)$ are negative which indicate that the reaction is spontaneous and exothermic. The $E_{\mathrm{a}}$ values indicate that adsorption occur through physical mechanism. Obtained results from above three methods are in good agreement with each other.

\section{References}

Abd S A and El-Makasoud 2002 Corros. Sci. 44803

Abdel Kader J M and El Din Shams A M 1970 Corros. Sci. 10551 Ajmal M, Mideen A S and Quraishi M A 1994 Corros. Sci. 3679

Al-Andis N, Khamis E, Al-Mayoufand A and Aboul-Enein H 1995 Corros. Prev. Cont. 4213

Ashassi-Sorkhabi H, Masoumi B, Ejbari P and Asghari E 2009 J. Appl. Electrochem. 391497

Ashassi-Sorkhabi H, Shabani B, Aligholipour B and Seifzadeh D 2006 Appl. Surf. Sci. 2524039

Ashassi-Sorkhabi H, Shaabani B and Seifzadeh D 2005 Appl. Surf. Sci. 239154

Avc G 2008 Colloids Surf. A317 730

Aytac A, Ozmen U and Kabasakaloglu M 2005 Mater. Chem. Phys. 89176

Bain C D, Throughton E B, Tao Y T, Evall J, Whiteside G M and Nuzzo J G 1989 J. Am. Soc. 111321

Desai M N, Desai M B, Shah C B and Desai S M 1986 Corros. Sci. 26827

Desai M N, Talati J D and Shah N K 2003 Indian J. Chem. 42A 3027

Desai M N, Talati J D and Shah N K 2008 Anti-Corros. Meth. Mater. 5527

Desai P S and Vashi R T 2010 Indian J. Chem. Technol. 1750

El Mahdy G A and Mahmoud S S 1995 Corros. Sci. 51436

Emregul K C, Kurtaran R and Atakol O 2003 Corros. Sci. 452803

Eyring and Eyring 1967 Modern chemical kinetics (New York: Reinhold) p. 7 
Gomma G K and Wahdan M H 1995 Mater. Chem. Phys. 39 209

Hackerman N 1954 Ind. Eng. Chem. 461481

Hahner G, Woll C, Buck M and Grunze M 1993 Langmuir 91 955

Hosseini M G, Mertens S F L, Gorbani M and Arshadi M R 2003 Mater. Chem. Phys. 78800

Khaled K F and Qahtani M 2009 Mater. Chem. Phys. 113150

Li S L, Chen S, Lei S B, Ma H, Yu R and Liu D 1999 Corros. Sci. 411273

Li X, Nie X and Wang L 2005 Surf. Sci. Coat. Technol. 2001994

Ovari F, Tomcsanyi L and Turmezey T 1998 Electrochim. Acta 33 323

Rosliza R, Wan Nik W B, Izman S and Prawoto Y 2010 Curr. Appl. Phys. 10923

Sampat S S and Vora J C 1974 Corros. Sci. 14591
Shah N K, Agrawal Y K, Talati J D, Shah M D and Desai M N 2004 Corros. Sci. 46633

Shalaby L A, El Sobki K M and Abdel Azim A A 1976 Corros. Sci. 16637

Sherif E M and Park S M 2006 Electrochim. Acta 511313

Stevanovic R M, Despic A R and Drazic D M 1988 Electrochim. Acta 33397

Talati J D, Desai M N and Shah N K 2005a Mater. Chem. Phys. 9354

Talati J D, Desai M N and Shah N K 2005b Anti-Corros. Meth. Mater. 52108

Talbot D and Talbot J 1998 In Corros. Sci. Technol. (Florida: CRC Press LLC)

Tomcsanyi L, Varga K, Bartik I, Horanyi G and Maleczki E 1989 Electrochim. Acta 34855

Yurt A, Ulutas S and Dal H 2006 Appl. Surf. Sci. 253919 